\title{
Enhancing Capability of Tanjung Bumi Batik Sales Bangkalan Madura
}

\author{
Author \\ Astria Hindratmo, Ong Andre Wahyu Riyanto \\ Correspondence \\ Wijaya Putra Surabaya University
}

\begin{abstract}
Madura Island besides producing salt, it turns out that it is also the producer of the craft written batik. One of the regions that have batik-producing SMEs is in Tanjung Bumi Bangkalan Madura District. In Tanjung Bumi Subdistrict there are very many batik craftsmen with a distinctive bird motif. However, although there are many batik SMEs, there are also many craftsmen who close their businesses due to having several problems in their business. One of the problems is not having a good marketing concept and not being able to utilize information technology through the internet in marketing activities. This can be seen from the sales activities that still rely on shops and also just waiting for suppliers or buyers from outside the city such as from Surabaya. With the competition of batik sales outside the city, such as Surabaya, causing the number of buyers from Surabaya is currently decreasing. The decline finally drastically impacted the decline in sales of Tanjung Bumi written batik. The purpose of this activity is to provide knowledge and insight into designing 4P marketing mix concepts (Product, Price, Place, Promotion) and determining STP (Segmentation, Targeting, Positioning) and making SME partners begin to take advantage of internet technology for online advertising. The method used in this activity is to train to create marketing concepts and train the use of online media and social media to advertise. The result of this activity is that partners have the knowledge of designing marketing concepts and are able to innovate in marketing activities using information technology with the internet on social media.
\end{abstract}

Keywords: SME, marketing mix, STP, online advertising

Received: 26 Desember 2018. Accepted: 17 Januari 2019

\section{Introduction}

Batik is one of the original Indonesian crafts that have been set by a World organization called the United Nations Educational, Scientific and Cultural Organization (UNESCO) as an authentic Indonesian heritage (Bambang, 2009).

The batik that is most commonly known to people is that craft of Central Java and Yogyakarta , such as Solo batik, Yogyakarta batik, and Pekalongan batik (Vuldy, 1987). But if we look at the reality that batik is not only batik from Central Java and Yogyakarta.

Almost all regions in Indonesia also produce batik with the characteristics of their respective regions. One of the batik that has the characteristic is Madura batik.

Madura is divided into four regencies, namely Bangkalan, Sampang, Pamekasan, and Sumenep Regencies. Madura Island is known as a salt producer. But Madura in each Regency apparently has batik crafts with different motifs.
Batik products made by craftsmen from Madura have their own characteristics, namely motifs, striking colors, and unique production processes (Rakhmawati, 2016). As in Bangkalan Regency there is Tanjung Bumi written batik located in Tanjung Bumi District.

The typical Tanjung Bumi batik motif has a sharp color like red with the most designs of birds. Based on the Head of the Bangkalan Regency Industry and Trade Office, Tanjung Bumi artisans of written batik are the most in three villages, Ds. Paseseh, Ds. Tanjung Bumi, Ds. Telaga Biru and the number of batik artisans as many as 1121 people with a total number of business units of 658 business units (Taufiqurrahman, 2012).

Tanjung Bumi Batik is increasingly recognized by the public, especially buyers who come from Surabaya so that sales are increasing from year to year.

Many buyers from among agents, suppliers, to company employees who buy in large quantities. However, based on the results of the survey to the 
location directly from 2014 to 2018 there was a very sharp decline in which the decline in batik orders decreased by $70 \%$.

The average craftsman in his sale only relies on buyers who come directly to the store or order directly by visiting the craftsmen in his house. This shows that batik marketing carried out by craftsmen is just waiting for orders to arrive without any activity to pick up buyers or move to offer products to batik seller shops, especially stores in Surabaya.

\section{Identification of problems}

Since its establishment until now Tanjung Bumi batik craftsmen in management are still not able to design marketing concepts due to the determination of product segmentation, targeting, and positioning (STP) against competitors.

As a result the product is unable to compete with the type of printing batik or other areas that have low prices with clear targets, namely retail buyers. Segmentation is to divide market groups into several groups of characters or different needs (Kotler \& Armstrong, 2008).

Targetting is a form of choosing several predetermined market segmentations (Kasali, 1998). Positioning is how techniques determine sales locations that are clear, different, and targets that are market share desires (Kotler \& Armstrong, 2008).

In addition, there is also an understanding of the marketing mix which includes $4 \mathrm{P}$ namely a product, price, place, and promotion that is still lacking. Problems marketing management that occur with partners now have an impact not maximal of product sales.

Marketing Mix is basically a marketing strategy that aims to generate sales turnover by making customers satisfied. Marketing Mix technically identifies 4P (Product, Price, Promotion, Place) by synergizing the four components (Kotler \& Armstrong, 2000).

Besides that, until now partners have not been able to utilize internet information technology to sell online. Because with online marketing it will be able to get more batik sales opportunities and a wider marketing range.

Because so far only rely on buyers from Surabaya or surrounding areas. The use of information technology by advertising online can be through websites or social media applications. Because this will be very effective to help direct marketing as currently done.

The advantages of online advertising are advertisements that use the internet which are fastgrowing media so can reach narrow market targets, have fast time in designing advertisements with the web and relatively inexpensive costs (Kotler and Armstrong, 1997).

The target in this activity is that craftsmen have the ability to design the concept of marketing mix, which is to determine 4P (Product, Price, Place, Promotion).

Related to the determination of products, craftsmen can separate products based on batik motifs from difficult and consuming a long time ones up to batik with the usual design and not so difficult in making it.

Craftsmen must also make a difference in price according to batik cloth that has been separated according to the motives. Craftsmen are also able to determine the location of the sale according to the batik motif that has been separated based on the motif. Then craftsmen must also be able to carry out promotional activities that are right for each type of batik motif that has been separated before.

Then batik artisans have an interest in marketing products by utilizing internet-based information technology such as social media applications as an online marketing tool to increase sales and also so that Tanjung Bumi batik is better known by the wider community. So that it will be able to increase sales which in the past few years decrease.

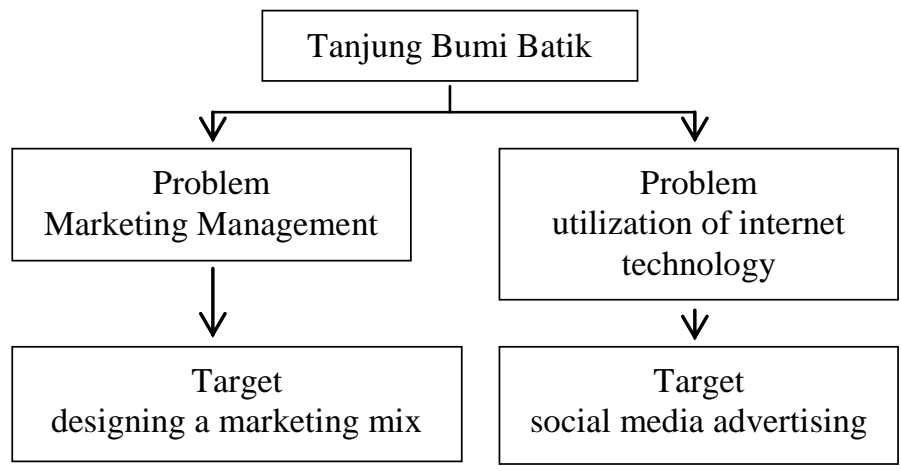

Figure 1: Problems and Target of SMEs

\section{Method}

The method used to solve the problems of Tanjung Bumi Batik SME partners is to use a 
series of seminar activities which is in concepts such as exposure or explanation and also training. The presentation and training included:

1. Training and exposure to marketing design concepts

This activity begins with exposure or direct explanation and design training for making marketing mix concepts based on 4P (Product, Price, Place, Promotion) and also training in determining segmentation, target and product position.

At training marketing mix making, partners are trained on how to design the right product, the right price, the right sales location, and design the right promotional strategy.

Then partners will be trained to make segmentation of customers, targets, and identify product positions with competitors. This training will be able to make partners create product variations that are more targeted according to the segmentation and predetermined targets so that product sales are more targeted and also increase sales from the previous year.

2. Training and exposure about online advertising

In this activity, partners will be explained about the great advantages and benefits of online advertising by utilizing online-based technologies such as social media, websites, and blogs on the internet.

In addition, partners are also trained on how to design online advertisements and create social media accounts as a means of promotion. This activity is expected to be able to increase knowledge and great interest for SME partners in developing marketing strategies through online advertising. In addition, it will also be able to increase the number of sales from the previous year.

Based on the method described previously, namely the material and equipment prepared in the training activities, namely:

1. Training activities in designing the marketing mix concept.

Equipment needed:

a. Notebook to give an example of making a marketing mix that is on the internet through information on Google. b. Whiteboard and markers to explain directly and verbally about the flow of marketing concepts.

2. Presentation activities and training in online advertising

Equipment needed:

a. Facebook social media accounts as an example to practice how the technique to make effective advertise words online.

b. Whiteboards and markers to explain in writing the benefits of advertising with social media and blog websites.

c. Notebook to practice directly in the operation of social media.

\section{Results and Discussion}

The dedication program activity is carried out in three stages, namely:

1. First Stage: Initial Identification, namely Visiting the condition of Tanjung Bumi Batik SME. At this stage, the implementing team came directly to the batik UKM in order to:

a. Seeing the condition of the place of sale of Batik, namely in the shop to find out the atmosphere of the sales and its location is crowded or quiet buyers.

b. To find out the problems and constraints of sales faced by interviewing Tanjung Bumi Batik craftsmen.

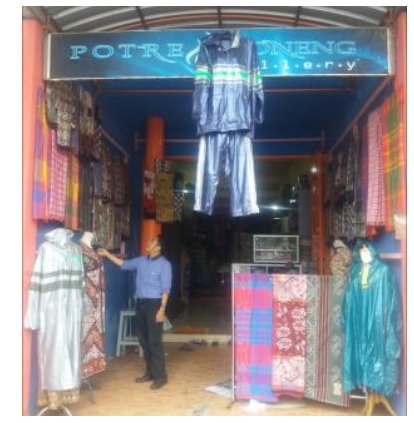

Figure 2. Conditions for batik sales place

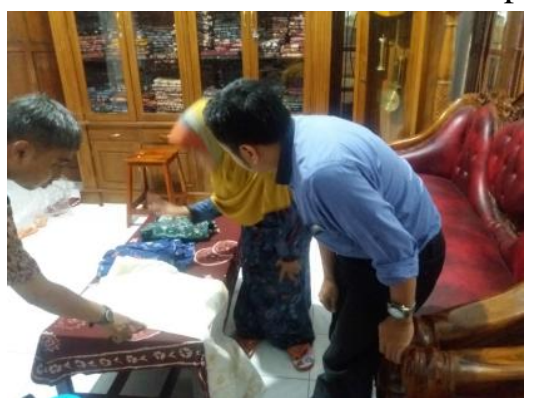

Figure 3. Interview with Craftsmen 
2. Second stage: Seminar in the concept of exposure because the participants are only SME owners. At this stage, it is done by:

a. Give an explanation of the importance of making more conceptual marketing by informing how to identify and determine 4P marketing mix (Product, Price, Place, Promotion) and how to determine STP (Segmentation, Targeting, Positioning). With this presentation, it is expected that craftsmen can design products that have been determined by segmentation and targets so that sales are more targeted and on target.

b. Giving knowledge to Batik craftsmen about the importance of advertising by online so motivate them to advertise online so that sales can rise again.

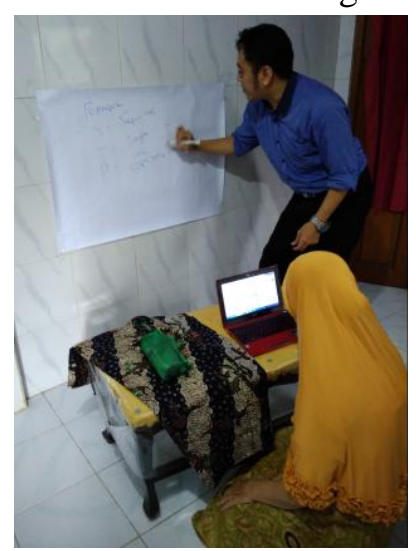

Figure 4. Explanation and Training on Marketing Mix Concepts and Online Advertising

c. Third stage: Training to marketing design with the concept marketing mix and determination STP (Segmentation, Targeting, Positioning)

At this training, stage craftsmen are trained to design the basics of the marketing mix and determine the segment, target, and position of the product compared to competitors. The objectives of this training are:

a. Giving ways to advertise online through social media accounts.

b. Giving confidence to craftsmen to always use social media websites for advertising facilities.
Table 1. Designing Tanjung Bumi Batik Mix Marketing Concept

\begin{tabular}{|c|c|c|c|}
\hline Product & Price & Place & Promotion \\
\hline Grade A & $\begin{array}{c}175.000- \\
200.000\end{array}$ & $\begin{array}{l}\text { Send out of } \\
\text { town }\end{array}$ & $\begin{array}{l}\text { Use the services of } \\
\text { middlemen and } \\
\text { social media }\end{array}$ \\
\hline Grade B & $\begin{array}{c}250.000- \\
350.000\end{array}$ & $\begin{array}{l}\text { Send out of } \\
\text { town }\end{array}$ & $\begin{array}{l}\text { Use the services of } \\
\text { middlemen and } \\
\text { social media }\end{array}$ \\
\hline Grade C & $\begin{array}{c}400.000- \\
600.000\end{array}$ & $\begin{array}{l}\text { Send out of } \\
\text { town }\end{array}$ & $\begin{array}{l}\text { Use the services of } \\
\text { middlemen and } \\
\text { social media }\end{array}$ \\
\hline Grade D & $\begin{array}{l}700.000- \\
1.000 .000\end{array}$ & $\begin{array}{l}\text { Batik Sales } \\
\text { Center (Home } \\
\text { of Craftsmen) }\end{array}$ & Online advertising \\
\hline $\begin{array}{c}\text { Grade } \\
\text { Exclusive }\end{array}$ & $\begin{array}{c}> \\
1.000 .000\end{array}$ & $\begin{array}{lr}\text { Batik } & \text { Sales } \\
\text { Center } & \text { (Home } \\
\text { of Craftsmen) }\end{array}$ & Online advertising \\
\hline
\end{tabular}

Table 2. Results of Designing a Marketing Strategy with the STP Concept

\begin{tabular}{|c|c|c|c|c|}
\hline $\begin{array}{c}\text { Type of } \\
\text { Batik } \\
\text { Motif }\end{array}$ & $\begin{array}{l}\text { Price } \\
\text { Range }\end{array}$ & Segmentation & Targeting & Positioning \\
\hline Grade A & $\begin{array}{c}175.000- \\
200.000\end{array}$ & $\begin{array}{c}\text { Office } \\
\text { employee }\end{array}$ & $\begin{array}{c}\text { Buyer } \\
\text { Level of } \\
\text { UMR } \\
\text { Salary }\end{array}$ & $\begin{array}{c}\text { Sharp and } \\
\text { bright } \\
\text { colors }\end{array}$ \\
\hline Grade B & $\begin{array}{c}250.000- \\
350.000\end{array}$ & $\begin{array}{c}\text { Office } \\
\text { employee }\end{array}$ & $\begin{array}{l}\text { Buyer } \\
\text { Level } \\
\text { UMR } \\
\text { salary up } \\
\text { to } 5 \\
\text { million }\end{array}$ & $\begin{array}{c}\text { Sharp color } \\
\& \text { variant } \\
\text { motives }\end{array}$ \\
\hline Grade C & $\begin{array}{c}400.000- \\
600.000\end{array}$ & $\begin{array}{c}\text { Office } \\
\text { employee }\end{array}$ & $\begin{array}{l}\text { Buyer's } \\
\text { Salary } \\
\text { Level is } \\
5-7 \\
\text { million }\end{array}$ & $\begin{array}{l}\text { Sharp color } \\
\text { \& more } \\
\text { complicated } \\
\text { motives }\end{array}$ \\
\hline Grade D & $\begin{array}{l}700.000- \\
1.000 .000\end{array}$ & $\begin{array}{c}\text { Office } \\
\text { employee }\end{array}$ & $\begin{array}{l}\text { Buyer's } \\
\text { Salary } \\
\text { Level is } \\
5-10 \\
\text { million }\end{array}$ & $\begin{array}{c}\text { Sharp color } \\
\& \text { the } \\
\text { motive is } \\
\text { very } \\
\text { complicated }\end{array}$ \\
\hline $\begin{array}{c}\text { Grade } \\
\text { Exclusive }\end{array}$ & $\begin{array}{c}> \\
1.000 .000\end{array}$ & $\begin{array}{c}\text { Community of } \\
\text { batik lovers }\end{array}$ & $\begin{array}{c}\text { Batik } \\
\text { collector }\end{array}$ & $\begin{array}{c}\text { Sharp } \\
\text { colors, } \\
\text { motifs, } \\
\text { better raw } \\
\text { materials }\end{array}$ \\
\hline
\end{tabular}

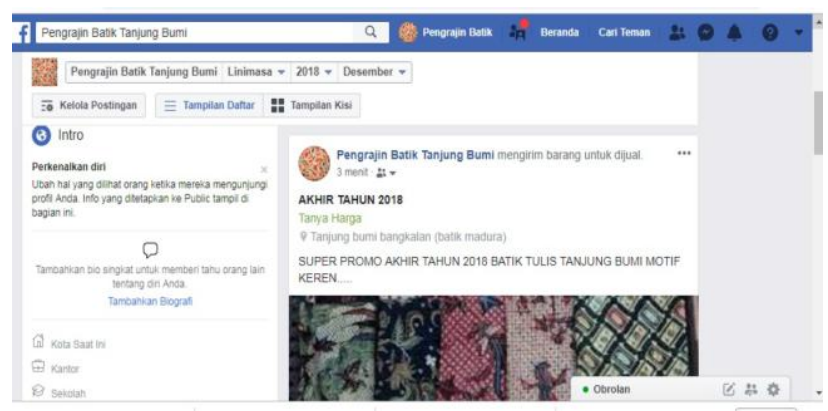

Figure 5. Design of Online Advertising of Tanjung Bumi Batik with Social Media Sites 


\section{Conclusion}

Based on the results of the discussion, it can be concluded as follows:

1. SME partners understand and are able to design the marketing mix concept well.

2. SME partners have been able to make STP (Segmentation, Targetting, Positioning) according to their business objectives.

3. SME partners already have the initiative and are interested in advertising online.

4. SME partners already have a Facebook social media account for tools advertise with online

\section{Reference}

Bambang. 2009. Unesco Setujui Batik Sebagai Warisan Budaya Indonesia dari http://www. antaranews.com/berita/153756/unescosetujui-batik-sebagai-warisanbudayaindonesia diakses pada 22 Oktober 2018.

Kasali, Renald. 1998. Membidik Pasar Indonesia, Segmentasi Targeting dan Positioning. Jakarta: PT Gramedia Pustaka Utama.

Kotler, Phillip dan Garry Armstrong. 1997. Dasar dasar Pemasaran. Alih Bahasa Alexander Sindoro. Jilid dua. Jakarta: Prenhalindo.

Kotler, Philip dan Gary Armstrong, 2000. Marketing Manajemen. Edisi millennium. Jakarta : Prenhallindo.

Kotler, Phillip, dan Gary Armstrong. 2008. Prinsip-Prinsip Pemasaran. Ed.12. Jakarta: Penerbit Erlangga.

Taufiqurrahman, 2012. Batik Tanjung Bumi, Bangkalan Madura, dari http://jawatimuran.net/2012/06/15/6479/,

Diakses pada 20 September 2018.

Vuldy.Chantal. 1987. Pekalongan: Batik Et Islam Dans Une Ville Du Nord De Java Dalam John N. Miksic (Review). Journal Of Southeast Asian Studies, Vol. 20, No. 2 (Sep., 1989), Pp. 336-338. 